during his brief tenure as he labored endless hours to nurture the scholarly content of that journal, standing uniquely at the crossroads of governmental and academic research. Despite the weight of editorial responsibilities, Frankel went on to pursue a doctorate at George Washington University. He moved with unassuming ease from the classroom to the podium at colloquia sponsored by the university's Institute for Sino-Soviet Studies. His dissertation-never completed-was to have been a study of the Marxist philosopher Moses Hess, about whom he had written (in German) in his early days as Yeshiva.

Ted Frankel also made his own personal contributions to the field of Communist studies. He participated in the Lenin Centenary Conference held at Oklahoma State University in April 1971 and in the Northeastern Slavic Conference at Montreal in May 1971. With economist John P. Hardt he coauthored an important chapter on Soviet economic managers in the seminal work Interest Groups in Soviet Politics, edited by $\mathrm{H}$. Gordon Skilling and Franklyn Griffiths (Princeton, 1971). And he returned to the pages of Commentary with a penetrating and erudite review of the Khrushchev memoirs.

Frankel's untimely passing was a loss to the broader community of scholars, but it came as a particular blow to his many close friends and associates in the Washington Chapter of the AAASS, of which he served as vice-president at the time of his death.

Wayne Hald

U.S. Information Agency, Washington, D.C.

\title{
HENRY L. ROBERTS, 1916-1972
}

Henry Roberts possessed qualities of mind and spirit rarely combined in one person: a rich and often tormented sensibility of his own, yet a capacity for intellectual and moral detachment and an empathy for the concerns of others which caused many to turn to him in times of doubts and troubles. This combination of qualities brought a grace to our lives which will be the poorer without him. Notwithstanding these exceptional qualities, Henry's person and life were characteristic of a whole generation of Americans, especially American academicians, who were suddenly swept out of their moorings by America's involvement in the Second World War to find themselves living lives they had not sought in the chaotic world of the war and immediate postwar years into which they felt imperiously called upon to restore an order.

Henry Roberts had studied at Yale to become a historian of Western Europe, but as a result of his wartime service in OSS he found himself in Rumania, immediately after the armistice of 1944 , watching with torment-and yet with his never-absent sense of irony-the disintegration, under Russia's shadow, of Rumanian society and politics. There was little that Henry could do about this chaotic drama and its eventual resolution, but it impelled him to write a book about the processes in Rumanian life between the two wars that had helped to bring it about. This book (Rumania: Political Problems of an Agrarian State, Yale University Press, 1951), a magisterial study of the interconnections of Rumanian economic and political life during the interwar period, led to Henry's selection in 1954 as the first head of Columbia's new program on East Central Europe, the beginning of two decades of a successful but overburdened career in academic and scholarly 
affairs during which Henry built an institute at Columbia and rebuilt another. Between 1954 and 1966 he turned Columbia's program on East Central Europe into an institute of considerable distinction, and from 1956 to 1962 he presided over the passage of the Russian Institute from one generation of scholars to the next. As time passed, Henry also found himself cast-not without moments of wry amusement-in the role of the wise old man of Columbia's history department, the one to whom his colleagues often turned to help resolve their conflicts.

At the end of his overburdened day at Columbia, Henry had to dash to the Council on Foreign Relations and the other charges to which he had been called by America's headlong postwar involvement in the affairs of the world. In and of themselves, Henry's duties at the Council would have taxed the resources of any man. He was responsible, month after month, for the myriad evaluations of books touching on international relations in the Council's journal, Foreign Affairs. He also presided over a number of research projects of the Council, and elaborated on the findings of two of them in books that he managed to write, even during these crowded years (Britain and the United States: Problems in Cooperation, with Paul Wilson, New York, 1953, and Russia and America: Dangers and Prospects, New York, 1956). And if this were not enough, Henry also took on between 1965 and 1967 the editorship of the Slavic Review, imbuing this journal with an elegance to which it had not been accustomed.

In the course of an extraordinarily busy life, he often found himself cast in roles for which he felt unprepared, but which he always managed to infuse with richness as well as style. He was able to do this-to perform always far better than he knew-not only because of the breadth and flexibility of his intelligence, and the sureness of his tact and sensibility, but also because less than any man I have known were his judgments ever shaded by any trace of intellectual envy. But as the years wore on, the life that Henry led at Columbia and in New York increasingly disheartened him. He felt desolate at the sight of an American society that seemed to be torn from its moorings and beset by doubts about its role in the world, and he sensed he had lost his balance and felt the need to recover it by seeking for himself and his dear ones a more personal and humane environment. He instinctively recoiled from the anger that so many others projected onto the world about them, as well as from the sweeping quality of their explanations for its predicaments. The anger he could not share, because he was not himself an angry man, and it was impossible for him to personalize evil, especially in those he knew. As for the sweeping explanations, he was by nature as wary of final answers as of final solutions. Indeed, he never divested himself of the Anglo-Saxon's native suspiciousness about grand generalizations. Above all, he resisted what he felt to be too rigid, too abstract, or too monolithic explanations for America's and the world's troubles.

The need to recover his roots and a life more to human measure eventually impelled Henry to give up his professorship at Columbia for one at Dartmouth in order to move permanently with his wife, Debby, and his family to Rochester, Vermont-there, to bring up another child and give her a richer and fuller life, to immerse himself with his dear ones in the life of their immediate community, and to merge and satisfy some of his emotional and intellectual needs by becoming the town's historian.

Henry during these years maintained a fruitful academic and scholarly existence. He plunged with zest into his teaching duties at Dartmouth, drawing far 
more pleasure from the challenge of teaching history to undergraduates than he had drawn from his previous administrative responsibilities. He also wrote a number of perceptive and elegant essays which eventually appeared, together with some of his previous writings, in a volume published two years before his death (Eastern Europe: Politics, Revolution, and Diplomacy, New York, 1970).

But more important, Henry recovered his serenity during these years in Vermont-and more. For him, the life on the farm-with the family, the cows, the old horse, the dogs, and the goat which constantly ran up and down the road-as well as the whole pattern of the life of the community around him became exemplars of whence America had come and what she should somehow seek to recover: of the capacity of people to recognize one another, keep counsel together, and give each other comfort. Thus we can find some consolation in the fact that, however harshly and prematurely the gods struck him, he did manage to complete his emigrant's journey of return and, however briefly, to enjoy its blessings.

\section{LEOPOLd H. Haimson Columbia University}

(These remarks are a revised and condensed version of reminiscences presented at the memorial service held for Henry L. Roberts at St. Paul's Chapel, Columbia University, November 1, 1972. A booklet containing the tributes presented at this service and a short biography can be obtained by writing to the Russian Institute, Columbia University, 420 West 118th Street, New York, New York 10027.) 